
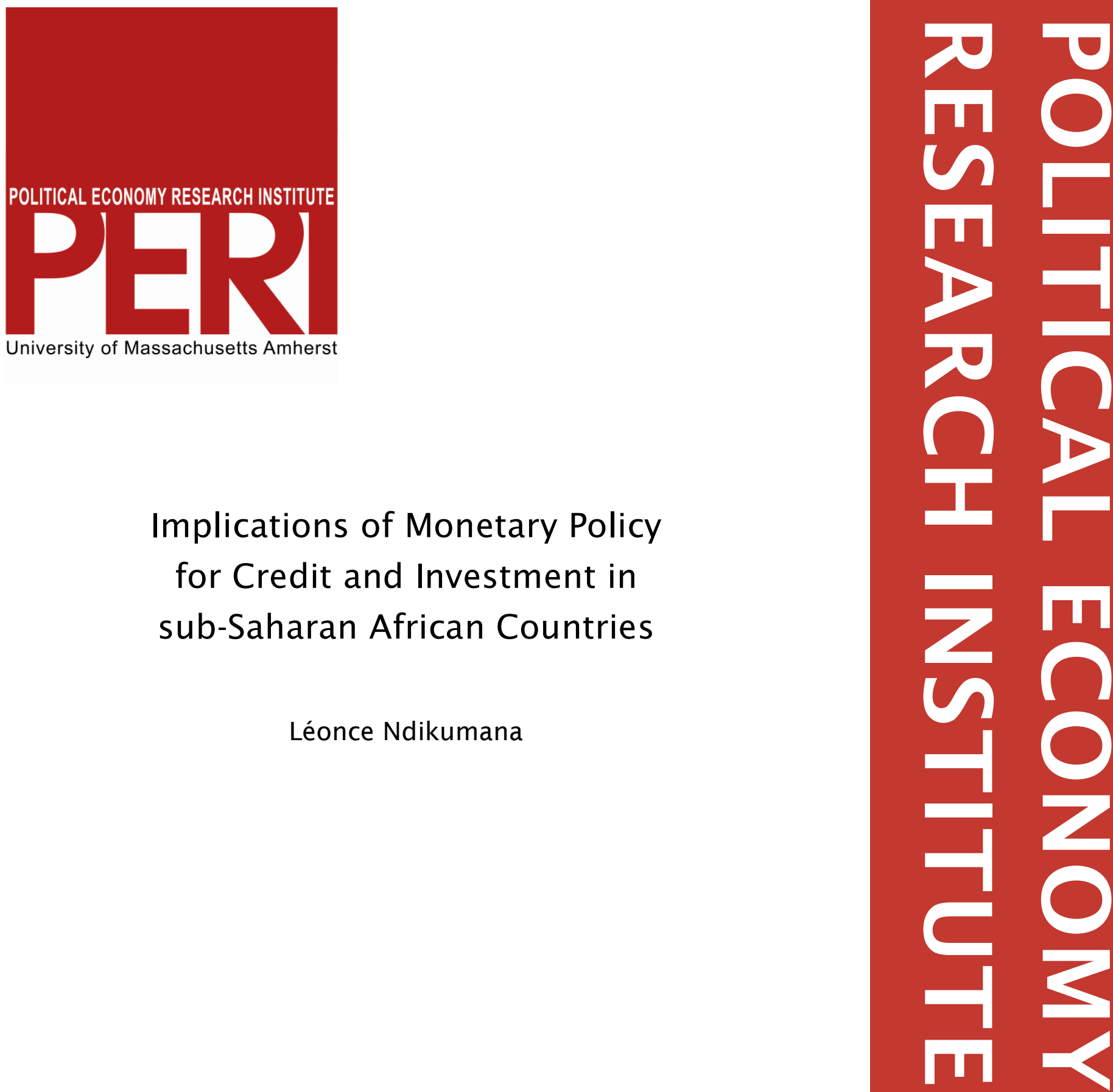

Implications of Monetary Policy for Credit and Investment in sub-Saharan African Countries

Léonce Ndikumana

August 2014 


\title{
Implications of monetary policy for credit and investment in sub-Saharan African countries
}

\author{
Léonce Ndikumana ${ }^{*}$ \\ Department of Economics and Political Economy Research Institute (PERI) \\ University of Massachusetts at Amherst \\ Email:ndiku@econs.umass.edu \\ Website: www.ndikumana.com; www.peri.umass.edu
}

This draft: August 12, 2014

\begin{abstract}
This paper investigates the implications of monetary policy for domestic investment through its effects on bank lending to the private sector and interest rates in sub-Saharan African countries. The study argues the pursuit of inflation control through contractionary monetary policy carries high costs in terms of reduced investment and ultimately slower economic growth. The econometric evidence based on a sample of 37 sub-Saharan African countries over 1980-2012 shows that contractionary monetary policy affects domestic investment negatively both indirectly through the bank lending or quantity channel as well as directly through the interest rate or cost of capital channel. The results suggest that policies that maintain a low interest rate regime would stimulate bank lending to the private sector, which in turn would boost domestic investment. The results have important policy implications for African countries in their efforts to achieve and sustain high growth rates as a means of reaching their national development goals notably employment creation and poverty reduction.
\end{abstract}

Key words: domestic investment; bank credit; monetary policy; interest rates; subSaharan Africa; inflation targeting; growth

JEL classification: E22; E42; E52; O23 ; O55

\footnotetext{
* Acknowledgements: This paper was completed during a fellowship residency at the Stellenbosch Institute of Advanced Studies (STIAS) in July-August 2014. I am grateful to STIAS for providing me with such an intellectually stimulating environment. Comments from participants at the STIAS Fellows Seminar are greatly appreciated. I sincerely thank Stan Du Plessis and members of the Monetary Economics Group in the Department of Economics at the University of Stellenbosch for constructive and stimulating discussions on monetary policy in Africa in general as well as some elements of this specific paper.
} 


\section{Introduction}

Since the 1980 s and more so over the past decade, there has been a gradual convergence of monetary policy regimes in African countries towards inflation control as the overriding objective of monetary policy (Heintz and Ndikumana, 2011; Honohan and O'Connell, 2008; Kasekende and Brownbridge, 2011; O’Connell, 2011). In fact two African countries have already formally moved to full-fledged inflation targeting (South Africa and Ghana) while two others (Mauritius and Uganda) have adopted a transition regime of informal inflation targeting or inflation targeting 'lite' (Porter and Yao, 2005). In practice this monetary policy orientation has been characterized by controlling domestic credit as a means of containing domestic demand and therefore reducing inflation and keeping it in check. In 2000, South African Finance Minister Trevor Manuel stated that high domestic credit extension is an obstacle to development and a constraint to monetary policy. ${ }^{2}$ He put is as follows: "Living beyond our means has become part of the national psyche. It is saddening. We would like to bring down interest rates, but as long as private credit extension is so high, that counteracts development."3 In fact, given that many African countries live with chronic budget deficits and that fiscal policy is out of control of the monetary policy authority, contractionary credit policy ultimately amounts to squeezing bank lending to the private sector. This paper argues that this policy orientation has adverse effects on the economy, especially by constraining private

\footnotetext{
${ }^{1}$ For a definition of "inflation targeting lite" regime, see Stone (2003).

${ }^{2}$ For a discussion of past and recent developments in South African monetary policy, especially on inflation targeting, see Du Plessis (2002).

3 Saturday Star Business Report, 12 August 2000. Cited in South African Institute for Race Relations (2000, p. 442).
} 
investment. The paper aims to explore this important issue and provide empirical evidence on sub-Saharan African (SSA) countries.

Investigating the linkages between domestic investment and monetary policy especially through the credit channel is important for several reasons in the case of SSA countries. While bank credit plays an essential role in financing investment in all economies, bank credit is of vital importance in SSA countries in particular. ${ }^{4}$ Because of pervasive information asymmetries, poorly developed or inexistent equity markets and other nonbank credit instruments, firms in SSA countries rely on bank credit as the primary source of external financing capital accumulation. Consequently, credit contraction is likely to cause relatively higher contraction in private sector activity in SSA countries than in more advanced economies. Second, there are important differences in the mechanisms through which monetary policy affects credit in advanced economies compared to SSA economies. In financially developed countries, it may be argued that the equilibrium quantity of credit is demand determined in the sense that commercial banks accommodate demand for credit at pre-determined price and non-price conditions. ${ }^{5}$ The Central Bank's role is to set the interest rate, which influences the rates at which banks are willing to lend. Borrowers adjust their use of line of credit in response to changes in the interest rate. In this context, banks operate as "retailers of credit" (Moore, 1989). Factors that determine the demand for credit, which are not directly influenced by monetary policy,

\footnotetext{
${ }^{4}$ See Ndikumana (2005) for a discussion of the role of financial development for investment.

${ }^{5}$ This argument has been developed in the Post-Keynesian literature on endogenous money. For instance, Moore (1989, p. 70) puts it as follows: "since new loans are undertaken at the initiative of bank borrowers, loan volume is largely a nondiscretionary and exogenous variable from the view point of the individual banks." For extensive discussions of money endogeneity, see, among others, Howells (1995) and Pollin (1991).
} 
are the ultimate determinants of equilibrium credit. In this context, the role of the Central Bank for domestic credit determination may be relatively limited.

In the case of SSA countries, in contrast, banks (i.e., the supply side of the credit market) ultimately determine the volume and allocation of credit. Indeed, the typical firm in an African country is a credit constrained unit, not one enjoying an idle line of credit at a commercial bank. Even the few African countries that are classified as emerging markets remain characterized by financial dualism, as only a small fraction of the private sector has easy access to bank credit while the majority of businesses are credit constrained. It would be difficult to argue that credit demand determines equilibrium credit in these countries. In this context, the Central Bank can potentially constrain domestic credit by raising the interest rate (the relative price channel) and through other policies that can discourage lending. Furthermore, the lack of competition in the banking sector also causes equilibrium credit to be supply determined rather than demand determined.

This study emphasizes the effects of monetary policy on domestic investment through the interest rate or cost of capital and through credit contraction to document real-side effects of monetary policy. One weakness of the monetarist orientation of monetary policy is that it ignores the effects of contractionary monetary policy on the supply side of the economy. A shortage in domestic credit constitutes a constraint on capacity utilization, investment, and employment in the business sector. Therefore, as Blinder (1987, p. 336) puts it, "credit restrictions, which reduce the supply of credit for either working capital or investment, are a major channel through which financial policies have real effects." If these supply effects are substantial, there may not be a trade-off between price stability 
and output growth. The upward pressure on the price level may offset the demand-side effects on inflation, reducing the effectiveness of contractionary monetary policy in controlling inflation. In particular, this study argues that tight monetary policy constrains capital accumulation by increasing the costs of borrowing, by reducing the pool of loanable funds in the banking system and by increasing the cost of debt due to interest rate hikes. As the cost of production increases, the prices of goods and services also increase. Ultimately, the costs are passed on from firms to consumers. Thus the focus on inflation stabilization as a gauge for success of policy may be problematic. Indeed, while many African countries may have been able to bring down inflation to lower levels, ${ }^{6}$ they face the more daunting challenge of achieving and sustaining high growth rates, which requires, among other things, raising domestic investment rates.

It is important to examine supply-side effects of (contractionary) monetary policy SSA countries for several reasons. First, monetary policy has important distributional effects which are overlooked in analyses that only focus on implications of monetary policy for inflation from a demand side perspective. If credit is curtailed due to contractionary monetary policy, then only the relatively better endowed households and firms will have access to credit. Moreover, as firms are forced to cut down employment and investment, the unskilled workers are the primary targets for layoffs. Therefore, credit constraints may contribute to increasing income inequality. Second, tight monetary policy has important open-economy effects that have implications for employment and inflation.

\footnotetext{
${ }^{6}$ The following statement by Mr. Emmanuel Tumusiime-Mutebile, Governor of the Bank of Uganda illustrates the enthusiasm regarding recent success with monetary policy: "Over the past two or three decades, monetary targeting frameworks have served sub-Saharan countries quite well. Monetary targeting brought down inflation in many low income countries, including Uganda in the early 1990s, and maintain it at moderate levels for sustained periods.”(Tumusiime-Mutebile, 2014)
} 
Low domestic credit, high interest rates, and a strong national currency undermine export competitiveness. As exports decline due to tight monetary policy, this leads to a deterioration of the current account and an increase in imported inflation. These imported inflation effects are substantial in many African countries due to dependence on imported intermediate and final goods. The high pass-through of imported inflation to domestic inflation severely constrains effectiveness of monetary policy. ${ }^{7}$ These and other considerations of supply side effects of monetary policy call for careful examination of the full implications of monetary policy regimes in a context where sub-Saharan African countries are converging to regimes that explicitly commit to targeting a low inflation rate as the overriding goal of monetary policy.

An important aspect that is not explored in this paper is the linkages between monetary policy and fiscal policy and their implications for bank lending to the private sector and domestic investment. In particular, large fiscal deficits are associated with high interest rates, which undermine investment both directly and indirectly. The direct effects arise from the associated high cost of capital. The indirect effects arise from the tendency of banks to shift resources into government securities and away from lending to the private sector. Moreover, a weak fiscal position undermines public investment which is an indispensable stimulator for private investment. These linkages are worth investigating to provide a full picture of the role of macroeconomic policies for bank lending and domestic investment. Such an investigation is also useful for understanding the role played by fiscal policy in supporting an inflation-targeting monetary policy regime.

\footnotetext{
${ }^{7}$ See Fischer et al. (2013) for an illustration on the case of the Democratic Republic of Congo.
} 
The paper motivates a dynamic structural investment model that incorporates the role of domestic credit under the view that monetary policy affects the overall "state of domestic credit", which affects production for any given level of other inputs. The derived investment function implies a direct positive relationship between capital accumulation and domestic credit.

The empirical analysis is based on a sample of 37 SSA countries over 1980-2012. It aims to investigate the following: (1) the effects of contractionary monetary policy on capital accumulation through bank credit to the private sector; (2) the effects of monetary policy on investment through the interest rates or the cost of capital; and (3) the impact of monetary policy on private sector lending through the interest rates. This analysis helps to paint a full picture of the implications of monetary policy for domestic investment.

The rest of the paper is organized as follows. The next section briefly reviews developments in monetary policy regimes in Africa over the past decades. Section 3 discusses potential adverse real-side effects of contractionary monetary policy. Section 4 presents a theoretical model of the linkages between investment and credit. Section 5 specifies the empirical estimation equation, describes the estimation methods, and discusses the regression results. Section 6 concludes.

\section{Monetary policy regime shifts in African countries}

In the early post-independence years, monetary policy in African countries was seen as a "servant of national development". This period was marked by activist expansionary monetary policy with a predominant role of the government both as a banker (through 
government owned financial institutions) and a borrower. This approach proved ineffective over time, as it led to inflationary government borrowing while suffocating the development of private financial institutions. Over time African countries adopted various monetary regimes corresponding to shifts in economic doctrine and political orientation. Honohan and O'Connell (2008) provides a survey of monetary regimes in African countries from the 1960s to the 1990, and more recent developments are discussed in Heintz and Ndikumana (2011), Kasekende and Brownbridge (2011), and O'Connell (2011), among others.

Today, sub-Saharan African countries have declared price stability as the ultimate objective of monetary policy. ${ }^{8}$ In fact South Africa and Ghana have adopted a fullfledged inflation targeting regime, while Mauritius and Uganda operate a transition regime of inflation targeting 'lite'. ${ }^{9}$ Since the structural adjustment programs of the 1980s, sub-Saharan African countries gradually moved away from direct to indirect monetary policy, and pursued pure market oriented monetary policy where the price and allocation of credit are set by market forces rather than being administratively controlled by the Central Bank. In practice, however, the majority of sub-Saharan African countries consider commercial bank credit as critical guide for demand management in controlling inflation. Thus, SSA countries outside of the CFA common currency area have maintained some sort of credit ceilings for a long time (Honohan and O'Connell, 2008; South African Reserve Bank, 2001).

\footnotetext{
${ }^{8}$ In fact the majority of African central banks intrinsically take a 5 percent inflation rate as guide to monetary policy even when inflation targeting per se has not been explicitly institutionalized. An interesting empirical question is why $5 \%$ is preferred to higher rates as an optimal target in the context of developing countries. Why different countries choose an identical target inflation rate is an even more daunting empirical question.

${ }^{9}$ See South African Reserve Bank (2001). For a discussion of the history of monetary policy in South Africa, see, among others, Du Plessis (2002) and Padayachee (2001).
} 
From an operational perspective, in most SSA countries, monetary policy still uses monetary aggregates as a target towards controlling inflation. This approach has been criticized for both its conceptual limitations (Easterly, 2002) and its weak practical effectiveness. Indeed, attempts to control inflation by using monetary aggregates as intermediate targets generally fail, especially because it is very difficult to hit the targets. This is especially due to the instability in money demand arising from demand and supply factors. Important structural problems hamper the effectiveness of rigid monetary policy regimes, including the large and frequent supply-side shocks - especially food price shocks - as well as structural features of the financial systems in SSA countries which remain heavily dominated by a monopolistic banking sector.

The main issue pursued in this paper concerns the implications of the focus on monetary policy on inflation control under rather rigid frameworks where low inflation is sought to be achieved at all costs, including depressing domestic credit. The rigidity of monetary policy frameworks has other very important implications that are beyond the scope of this paper. In particular, lack of flexibility often leads central banks to inappropriately respond to supply shocks with excessive monetary contractions that actually exacerbate the initial supply-side effects. Berg et al. (2013) provide an illustration of this issue in the case of East African countries.

In the case of SSA countries, policies that seek to restrict domestic credit as a means of containing domestic demand and inflation ultimately exacerbate the negative effects of the already pervasive credit rationing by banks. Lack of competition in African banking systems keeps borrowing costs exorbitantly high. In addition, banks tend to lend to the 
same sectors that are deemed safe, which include large trading companies. African banks have little incentives to expand their customer base as long as they are able to maintain high profit rates while minimizing exposure to risk. ${ }^{10}$ Consequently in African countries, credit is supply determined. This implies that a monetary policy regime that explicitly raises the cost of lending will have significant negative effects on private sector activity.

\section{Adverse real-side effects of contractionary monetary policy}

One important problem with monetary policies that constrains domestic credit is that they may have substantial adverse supply effects. The conventional view is that tight monetary policy that results in credit contraction causes private expenditures (especially durable goods and investment) to decline, causing a decline in aggregate demand, which reduces inflation. The decline in credit is also supposed to cause a reduction in the demand for imports, which ameliorates the current account deficit and reduces (imported) inflation. If credit contraction had only aggregate demand effects, then central banks could indeed control inflation by using contractionary monetary policy.

However, availability of credit determines the ability of firms to accumulate capital and hire labor. Thus, credit contraction causes a decline in capacity utilization, employment, and production. Tight monetary policy, which is usually associated with high interest rates and a strong currency, particularly hurts export-oriented sectors by undermining international competitiveness. The decline in production and exports causes upward pressure on the price level and deteriorates the current account, causing inflation to accelerate. The increase in the price level results in a decline in real credit, which causes

\footnotetext{
${ }^{10}$ See Nkurunziza et al. (2012) for an illustration in the case of Burundi.
} 
investment and employment to decline further. If these supply effects are significant, contractionary monetary policy will fail to reduce and contain inflation.

The inability of monetary policy to control inflation has long been recognized even in the Real Business Cycle school of thought. Sargent and Wallace (1981, p. 1) pointed out that "even in an economy that satisfies monetarist assumptions, ..., Friedman's list of things that monetary policy cannot permanently control may have to be expanded to include inflation." 11 Friedman had argued that monetary policy could not permanently influence real output, employment, and real returns on assets, but that it could definitively influence inflation (Friedman, 1968). ${ }^{12}$ In practice, however, because monetary policy has both supply and demand effects, especially through the credit channel, contractionary monetary policy may be ineffective in controlling inflation while it has substantial adverse real effects.

Blinder (1987) offers a simple theoretical framework to illustrate that the supply side effects of tight monetary policy through credit contraction may outweigh the demand effects on the price level. In Blinder's model, supply $(y)$ is determined by factor utilization $(F)$, which in turn depends on real credit $(c / p)(c$ is nominal credit and $p$ is the price level):

$y_{t}=\gamma F_{t-1} ; F_{t}=\alpha(c / p)_{t} ; \quad y_{t}=\gamma \alpha(\mathrm{c} / \mathrm{p})_{\mathrm{t}-1} ; \quad$ where $\gamma<1 ; \alpha<1$

Aggregate demand $(d)$ is determined by income:

\footnotetext{
${ }^{11}$ A monetarist economy is characterized by (1) a close positive link between the monetary base and inflation (from the quantity-theory demand schedule for high powered money) and (2) the ability of the monetary authority to raise seignorage.

${ }^{12}$ See Du Plessis (2014) for a discussion of interpretations of Friedman's views on the role of monetary policy.
} 
$d_{t}=a+b y_{t} ; \quad$ where $0<b<1$

Equations 1 and 2 can be combined to yield aggregate demand as a function of real factor utilization and real domestic credit:

$d_{t}=a+b \gamma F_{t-1}=a+b \gamma \alpha(c / p)_{t-1}$

The price adjustment process is summarized in the following equation:

$\dot{p}_{t+1}=\lambda\left(d_{t}-y_{t}\right)$

It follows from the above relations that credit contraction decreases demand $(d)$, which causes the price level to decrease, but it also decreases supply (y) which causes the price level to increase. From equations 1 and 3, the effects of a one percent decrease in credit may have a larger effect on supply than on demand under reasonable assumptions about the values of the parameters $b, \gamma$, and $\alpha$ : as long as $b, \gamma, \alpha<1$, it follows that $b \gamma \alpha<\gamma \alpha$, so that $|d y / d(c / p)|>|d x / d(c / p)|$, implying that $\dot{p}>0$. Under these conditions, tight monetary policy is stagflationary as it causes output to decline while inflation accelerates.

Contractionary monetary policy arguably reduces inflation by reducing domestic aggregate demand. However, low aggregate demand may be a constraint to output expansion. In the case of SSA countries, domestic markets for goods and services are thin, which is a constraint to production. A contraction in bank credit to the private sector therefore depresses production. Under such circumstances, even if price stability were achieved, the economy may incur a high cost in terms of reduced investment, employment, and output. Therefore, the monetarist orientation espoused by central banks 
in SSA countries to control inflation may constrain domestic credit, which exacerbates credit rationing arising from market imperfections.

In the context of SSA countries, the negative effects of contractionary monetary policy on private credit are exacerbated by pressure from deficit financing. Contractionary monetary policy in the context of chronic budget deficits automatically creates a captive market for government debt. Given that government borrowing is outside of the control of the monetary authority, tight domestic credit amounts to squeezing credit to the private sector, ${ }^{13}$ which has negative effects on domestic investment.

\section{Modeling the effects of bank credit on domestic investment}

There is a large and well established literature on the determinants of investment and methodologies for empirical investigation of investment behavior. A selected list includes Baddeley (2003), Chirinko (1993), Jorgenson (1971), Junankar (1973), and Nickell (1978). Fazzari et al. (1988) provide theoretical motivation and empirical evidence on the importance of credit constraints for investment at the firm level. ${ }^{14}$ This study focuses on the implications of the links between monetary policy and bank credit for investment at the aggregate level. Here, we derive a testable relationship between investment and monetary policy to illustrate the effects of monetary policy on domestic investment through bank credit to the private sector. This relationship goes beyond the standard situations of credit rationing (Stiglitz and Weiss, 1981) and financial repression typically

\footnotetext{
${ }^{13}$ Indeed, it has been observed that even in countries that are members of a regional economic organization where monetary policy is delegated to a regional central bank, in practice the control over government borrowing is very limited (Fielding, 1999). Governments can find indirect ways of borrowing such as through parastatals.

${ }^{14}$ Also see Kaplan and Zingales () and Fazzari et al. (2000)
} 
examined in the development finance literature (McKinnon, 1973). In the case presented here, the monetary policy stance can be explicitly pro- or anti-domestic credit, which affects private investment. In addition to the usual interest rate effect, monetary policy affects investment through the quantity of credit and its overall effects on financial intermediation. By reducing overall financial intermediation, credit contraction depresses business investment and overall economic activity.

The role of the "state of credit" has been emphasized for a long time in the economic literature. Keynes (1973, p. 222) pointed out that "the banks hold the key position in the transition from a lower to a higher scale of activity... The investment market can become congested through shortage of cash. It can never become congested through shortage of saving." ${ }^{15}$ Well-functioning domestic credit markets facilitate long-term investment by pooling resources, thus resolving the firm's problem of mismatches between revenue and expenditure flows. Credit markets also stimulate investment by facilitating risk sharing among investors. In particular, limited liability associated with credit financing makes investors more comfortable in undertaking large long-gestation investment projects. As a result, increased access to low-cost credit stimulates domestic investment. Therefore, the "state of domestic credit" is an enhancing "X-factor" in the capital accumulation process.

The foregoing discussion suggests that a better credit environment, or abundant and affordable credit, is be associated with higher optimal capital stock. This can be formalized by the following equation:

$$
K_{t}^{*}=a+b X_{t}+Z_{t} \theta
$$

\footnotetext{
${ }^{15}$ Also see Moore (1989) for further discussion of the role of credit for business operations.
} 
where $\mathrm{X}$ is the indicator of the state of credit and $\mathbf{Z}$ is a vector of other determinants of investment demand. The adjustment to optimal capital stock is as follows:

$$
\Delta K_{t}=\gamma\left(K_{t}^{*}-K_{t-1}\right)
$$

where $\gamma$ is the flexible accelerator parameter assumed to be between 0 and 1. Gross investment, the sum of net investment and replacement, is given by:

$$
I_{t}=\Delta K_{t}+\delta K_{t-1}
$$

where $\delta$ is the depreciation rate. Combining the above three equations yields investment as a function of the "state of credit":

$$
I_{t}=a \gamma+b \gamma X_{t}+\theta \gamma Z_{t}+(\delta-\gamma) K_{t-1}
$$

Monetary policy also has direct effects on domestic investment through the interest rates. These will be tested empirically in the next section. The empirical analysis also takes into account the effects of other factors of private investment, notably growth, political risk and trade. Given that investment is inherently irreversible, undertaking a new investment project carries a certain degree of risk (Bernanke, 1983; Dixit and Pindyck, 1994). This risk will be higher the higher the level of economic and political uncertainty. Using various measures of economic and political instability, some studies have found that risk has a quantitatively significant negative effect on investment. ${ }^{16}$

\footnotetext{
${ }^{16}$ Fielding (1997) finds that uncertainty has a larger effect on non-traded capital goods than on traded capital goods in the case of South Africa. His results suggest that higher economic risk encourages more investment in traded capital goods (p. 366).
} 
International trade may have a positive or a negative effect on domestic investment. If the increase in trade is accompanied by a reduction in the cost of imported inputs and more access to export markets, then trade will stimulate domestic investment in the relevant sectors. However, trade openness may depress domestic private investment due to foreign competition. A number of studies have found that openness exerts a positive effect on domestic investment (see Ndikumana (2000) for evidence on sub-Saharan African countries). However, an important empirical issue is the difficulty in identifying the exact channels through which the effects of trade openness on investment actually operate. Another problem is measurement of openness. In particular, due to the lack of consistent data on trade policy indicators, empirical studies typically rely on measures of trade outcomes (imports plus exports) as proxies of trade policy indicators. In practice, however, a country may experience an increase in trade without any change in trade policy, as in the case of a resource-rich country during commodity price hikes. Conversely, trade policy reforms aimed at promoting exports (e.g., reduction in export duties) may not necessarily result in expansion of exports, especially if a country's products are not price elastic as is the case of agricultural products. These caveats must be kept in mind while interpreting the results on measure of openness.

\section{Empirical Analysis}

\subsection{Specification and estimation methodology}

Two empirical exercises are undertaken in this study. The first is an investigation of the impact of credit to the private sector and monetary policy indicators on domestic 
investment. This is accomplished by estimating the following empirical investment model:

$$
I_{i t}=\alpha_{0}+\alpha_{1} X_{i t}+Z_{i t} \beta+\varepsilon_{i t}
$$

where $I$ is domestic investment (as a percentage of GDP), $X$ is alternatively domestic credit and indicators of monetary policy (the discount rate, the Tbill rate, and the lending rate), $\mathbf{Z}$ is a vector of other determinants of domestic investment, namely real GDP growth, total trade (as a percentage of GDP) and a political freedom index ${ }^{17}$ and $\varepsilon_{i t}$ is an error term.

The second empirical exercise is an assessment of the direct effects of monetary policy on domestic credit. This is done by estimating the following model:

$$
c_{i t}=\delta_{0}+\rho_{1} m_{i t}+Z_{i t} \beta+\mu_{i t}
$$

where $c$ is bank credit to the private sector (as a percentage of GDP), $m$ represents an indicator of monetary policy (alternatively the discount rate, the Tbill rate, and the lending rate), and $\mathbf{Z}$ includes the same variables as in equation 9 .

The models in equations 9 and 10 are estimated using the Arellano-Bover/Blundell-Bond dynamic panel data estimation methodology (Arelano and Bond, 1991; Arellano and Bover, 1995; Blundell and Bond, 1998). The dynamic formulation of the models takes into account the fact that capital accumulation is a long-gestation phenomenon. In the case of banking, lagged credit carries pertinent information on future bank behavior as

\footnotetext{
${ }^{17}$ The political freedom index is a composite index that combines the political rights and civil liberty indexes and it ranges from 0 to 6 where a high number reflects more political freedom.
} 
well as the future state of demand for credit. The dynamic panel data estimation technique allows us to account for endogeneity of regressors. In this study, real GDP growth, credit and the lending rate are explicitly considered as endogenous. The variables are entered into the regressions in logarithm, except for GDP growth rate which can take negative values. This enables us to interpret the regression coefficients directly as estimated elasticities of the endogenous variable relative to the relevant regressor.

\subsection{Highlights from the data}

The empirical analysis is based on a sample of 37 SSA countries over 1980-2012. The data are obtained from the World Bank's World Development Indicators, the IMF's International Financial Statistics and the Freedom House database, all of which are accessible online. The list of regression variables and data sources are provided in Table A.1 in the appendix. The list of countries in the sample is also provided under Table A.1. Summary statistics for these variables are reported in Table A.2 in the appendix. One key highlight from the data is that bank credit to the private is generally low in SSA countries in absolute terms and relative to other regions. To illustrate this fact, the average ratio of bank credit to the private sector over GDP for SSA countries is compared to that of a sample of 43 developing countries and 37 developed countries (the selection of the countries was based on data availability). The decadal averages are depicted in Figure 1. As can be seen in this graph, SSA countries have systematically trailed behind other regions in bank lending to the private sector. In fact, the gap between SSA and countries has increased over time. In the 1970s, the average ratio of bank credit to GDP was $15 \%$ in SSA compared to $21.4 \%$ for non-SSA developing countries; that is 1.4 times higher for 
the latter group than SSA. Over the period of 2000-12, the proportion was 2.3 times in favor of the non-SSA developing countries ( $42.4 \%$ compared to $18 \%$ for SSA). The low performance in bank lending may be one of the driving factors of the sluggish performance in domestic investment in SSA. ${ }^{18}$ The econometric evidence presented in the next section supports this postulate.

Figure 1: Bank credit to the private sector ( $\%$ of GDP), averages by decade

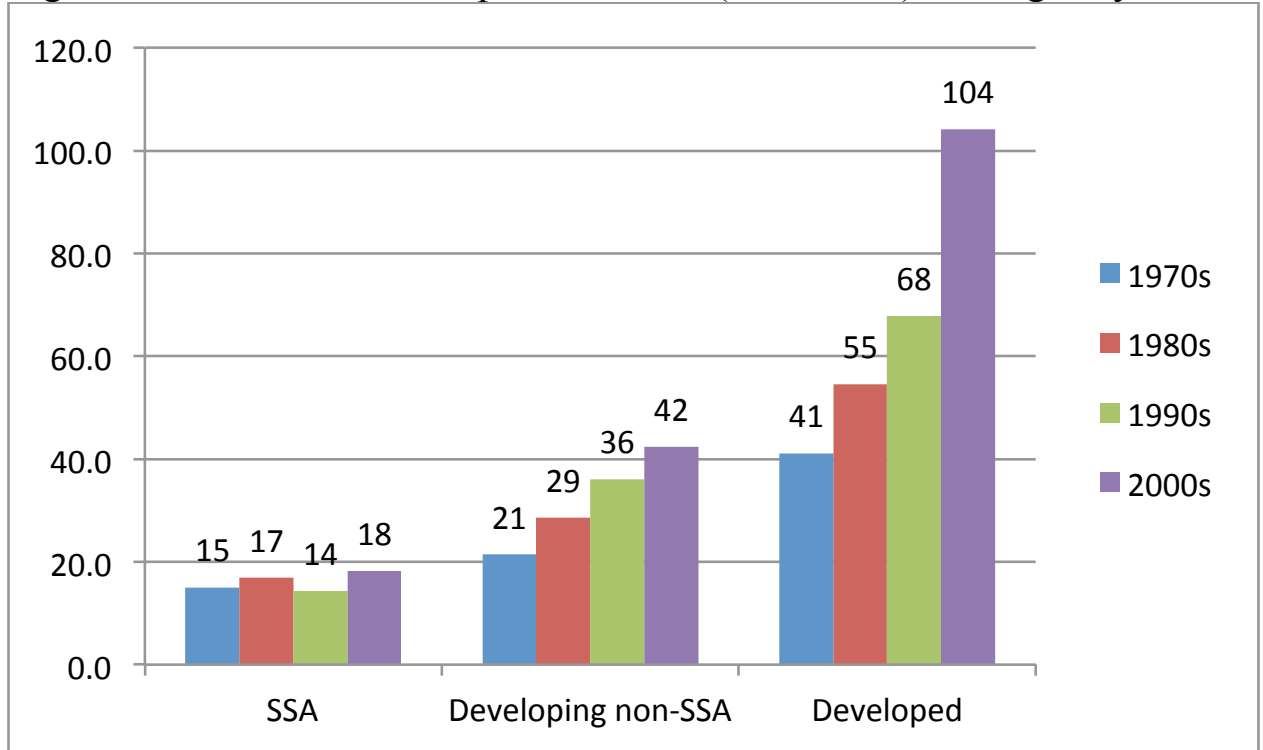

Source: World Bank, World Development Indicators (online).

Note: SSA = sub-Saharan Africa. The "Developing non-SSA" group contains 43 developing countries and the "Developed" group includes 37 developed countries. The groups by income are determined using the World Bank's income-based classification.

\subsection{Econometric estimation results}

Two sets of results are discussed in this section. The first set contains the econometric estimation results for the test of the impact of domestic credit and monetary policy indicators on domestic investment. These are presented in Table 1. The second set includes the regression results for the test of the impact of monetary policy indicators on domestic bank credit to the private sector. They are presented in Table 2.

\footnotetext{
${ }^{18}$ See UNCTAD (2014) for comparisons of trends in investment performance between Africa and other regions over the past decades.
} 
The results in Table 1 systematically support the view that bank credit is important for domestic investment in SSA countries. The coefficient on bank credit to the private sector is positive and statistically significant. Note, however, that the estimated elasticity of the impact of credit on domestic investment is relatively small. This is not surprising because while credit is important, other non-financial factors are also important drivers of domestic investment. In particular, political stability is an important factor, as illustrated in the positive and significant coefficient on the political freedom index. Moreover, access to international markets for imports and exports is a major factor of domestic investment as indicated by the large positive and statistically significant elasticity of investment relative to total trade. The results suggest that the shortage of bank lending to the private sector exacerbates the negative impact of other structural and institutional constraints to domestic investment in SSA countries.

In addition to credit, monetary policy indicators also have significant effects on domestic investment in SSA countries. Specifically, domestic investment is negatively and significantly affected by the discount rate, the Treasury bill rate and the bank lending rate. In other words, high policy rates and market interest rates effectively depress domestic investment in SSA countries. Thus, contractionary monetary policy achieved by raising the discount rate ultimately hurts domestic investment. Furthermore, high lending rates resulting in part from a high policy rates ultimately discourage domestic investment. The negative effect of the Treasury bill rate on domestic investment may reflect both a price effect and a substitution effect. On the one hand, a high Treasury bill rate is associated high levels of other market interest rates including the lending rate, which discourages domestic investment. Second, a high Treasury bill rate may cause crowding 
out of bank lending to the private sector by government borrowing. Given a high remuneration rate on government debt, banks may prefer to hoard government securities and reduce lending to the private sector. Large firms may also engage in similar arbitrage between investing their retained earnings in government securities and spending their funds on physical capital expansion. These effects may explain the negative relationships between interest rates and domestic investment in SSA countries.

The negative effects of monetary instruments and bank credit on investment may also reflect the fact that firms in SSA countries have few alternatives to bank lending for financing. Outside of South Africa, equity markets remain underdeveloped or nonexistent. Furthermore, a key feature of SSA financial systems is the lack of long-term investment capital, which limits funding opportunities for large and long-gestation investment projects. As a result, a shortage of credit and a high cost of credit are likely to be associated with lower domestic investment.

Table 1: Impact of credit and monetary policy indicators on investment in SSA countries

\begin{tabular}{lcccc}
\hline Explanatory variables & $(1)$ & $(3)$ & $(4)$ & $(2)$ \\
\hline Private credit & $0.080^{* * *}$ & & & \\
Discount rate & $(0.004)$ & $-0.059^{*}$ & & \\
& & $(0.098)$ & & \\
Treasury bill rate & & & $-0.073^{* *}$ & \\
& & & $(0.025)$ & \\
Lending rate & & & $-0.132^{* *}$ \\
& & & & $(0.022)$ \\
Lagged investment & $0.611^{* * *}$ & $0.590^{* * *}$ & $0.628^{* * *}$ & $0.642^{* * *}$ \\
& $(0.000)$ & $(0.000)$ & $(0.000)$ & $(0.000)$ \\
GDP growth & $0.010^{* * *}$ & 0.004 & 0.004 & $0.005^{*}$ \\
& $(0.010)$ & $(0.343)$ & $(0.164)$ & $(0.066)$ \\
Lagged GDP growth & -0.000 & 0.000 & -0.003 & -0.002 \\
& $(0.984)$ & $(0.864)$ & $(0.220)$ & $(0.441)$ \\
Total trade & $0.269^{* * *}$ & $0.396^{* * *}$ & $0.264^{* * *}$ & $0.256^{* * *}$ \\
& $(0.001)$ & $(0.001)$ & $(0.000)$ & $(0.000)$
\end{tabular}




\begin{tabular}{lcccc} 
Political freedom index & $0.068^{* *}$ & $0.063^{*}$ & 0.039 & 0.053 \\
& $(0.029)$ & $(0.065)$ & $(0.201)$ & $(0.148)$ \\
Constant & -0.284 & -0.387 & 0.133 & 0.296 \\
& $(0.231)$ & $(0.314)$ & $(0.583)$ & $(0.206)$ \\
& & & & \\
Observations & 1,051 & 581 & 829 & 829 \\
Number of countries & 37 & 20 & 36 & 36 \\
\hline
\end{tabular}

The dependent variable is domestic investment (\% of GDP). All regression variables are in logarithm except for the GDP growth rate. Robust $\mathrm{p}$-values are given in parentheses; statistical significance: *** $\mathrm{p}<0.01, * * \mathrm{p}<0.05, * \mathrm{p}<0.1$

Having established that bank credit has a significant positive impact on domestic investment, we now use the results in Table 2 to answer the question of whether monetary policy indicators have an effect on domestic credit. As can be seen from the table, credit is negatively and significantly related to the interest rates. Specifically, the central bank's policy instruments have a direct negative impact on bank credit to the private sector. This is illustrated by the negative and statistically significant coefficient on the discount rate. Market interest rates also have a negative impact on bank credit. The results show a negative and significant coefficient on the Treasury bill and the bank lending rate.

The negative effect of the Treasury bill rate on bank credit to the private sector is an illustration of the crowding out effect mentioned above. Specifically, a high Treasury bill rate induces commercial banks to invest in government securities, which are already deemed safer than credit to production units. As a result, investment capital is shifted away from the private sector to financing government deficits. The negative effect of the Treasury bill rate on bank credit may also reflect the negative impact of the general level of interest rates in the markets on both demand and supply of credit, given the comovement among interest rates. 
The latter point made about the effect of the Treasury bill rate is confirmed by the negative and statistically significant coefficient on the lending rate. The results show that the lending rate has the largest negative effect on bank lending to the private sector. The lending rate also has the largest effect on domestic investment as seen in Table 1. From the demand side, a high lending rate discourages borrowing as it reduces the pool of investment projects that can generate sufficiently high rates of return to cover debt service. From the supply side, a high lending rate discourages lending as it increases the default risk.

Taken together, the results in Tables 1 and 2 suggest that monetary policy has direct as well as indirect effects on domestic investment in SSA countries. Specifically, on the one hand, by setting high interest rates to reduce inflation and maintain it at low rates, the central banks raise the cost of capital which discourages domestic investment. This is reflected in the negative coefficient on interest rates in the domestic investment equation. On the other hand, contractionary monetary policy discourages the demand and supply of bank credit to the private sector, which in turn constrains domestic investment. So the impact on investment may arise through a cost of capital effect (through the interest rates) and a financing constraint effect (through bank credit).

Table 2: Impact of monetary indicators on bank credit in SSA countries

\begin{tabular}{|c|c|c|c|}
\hline Explanatory variables & (1) & (2) & (3) \\
\hline Discount rate & $\begin{array}{c}-0.070^{* * *} \\
(0.005)\end{array}$ & & \\
\hline Treasury bill & & $\begin{array}{c}-0.086^{* *} \\
(0.011)\end{array}$ & \\
\hline Lending rate & & & $\begin{array}{c}-0.157^{* * * *} \\
(0.000)\end{array}$ \\
\hline Lagged private credit & $\begin{array}{c}0.902 * * * \\
(0.000)\end{array}$ & $\begin{array}{c}0.869^{* * *} \\
(0.000)\end{array}$ & $\begin{array}{c}0.871^{* * *} \\
(0.000)\end{array}$ \\
\hline
\end{tabular}




\begin{tabular}{lccc} 
GDP Growth & -0.002 & -0.002 & -0.003 \\
& $(0.470)$ & $(0.448)$ & $(0.272)$ \\
Lagged GDP growth & $0.005^{* *}$ & $0.005^{* *}$ & $0.004 * *$ \\
& $(0.046)$ & $(0.012)$ & $(0.005)$ \\
Total trade & $0.102 * *$ & 0.056 & $0.087 *$ \\
& $(0.047)$ & $(0.268)$ & $(0.052)$ \\
Political freedom index & 0.007 & $0.054^{* *}$ & 0.019 \\
& $(0.742)$ & $(0.016)$ & $(0.273)$ \\
Constant & -0.035 & $0.295^{*}$ & $0.415^{* * *}$ \\
& $(0.831)$ & $(0.075)$ & $(0.001)$ \\
& & & 826 \\
Observations & 578 & 826 & 36 \\
Number of countries & 20 & 36 & \\
\hline Note: The dependent variable is credit to the private sector (\% of GDP). All regression variables \\
are in logarithm except for the GDP growth rate. Robust $\mathrm{p}$-values are given in parentheses; \\
statistical significance: $* * * \mathrm{p}<0.01, * * \mathrm{p}<0.05, * \mathrm{p}<0.1$
\end{tabular}

\section{Conclusion}

This study sought to investigate the real-sector implications of monetary policy in SSA countries in the context of the predominant contractionary monetary policy stance. Specifically, the paper investigated the implications of monetary policy for domestic investment. The empirical evidence shows a positive link between bank credit to the private sector and domestic investment, suggesting that monetary policy regimes that involve contraction of domestic credit as a means of containing inflation constitute a constraint to domestic investment. Moreover, the econometric results presented in this paper show a negative effect of monetary policy indicators on domestic investment and bank lending in SSA countries. In particular, a high lending interest rate appears to be a significant constraint to bank lending and domestic investment.

The results in this study suggest that monetary policy has direct and indirect effects on domestic investment. On the one hand, contractionary monetary policy discourages domestic investment because of the high interest rate regime that is maintained as a way 
of reducing inflation and containing it at low rates. On the other hand, high interest rates also discourage bank lending, which further depresses investment. Therefore, contractionary monetary policy is a constraint to domestic investment both through the cost of capital effect and the bank credit channel. To the extent that such a policy stance effectively brings inflation under control, this may be achieved at substantial real-sector costs in terms of depressed investment and therefore retarded long-term economic growth.

\section{References}

Arelano, M. and Bond, S. (1991). Some tests of specification for panel data: Monte Carlo Evidence and an application to employment equations. Review of Economic Studies, 58, 277-297.

Arellano, M. and Bover, O. (1995). Another look at instrumental variables estimation of error-component models. Journal of Econometrics, 68, 29-51.

Baddeley, M. C. (2003). Investment: Theories and Analysis. London: Palgrave.

Berg, A., Charry, L., Portillo, R. and Vlcek, J. (2013). The monetary transmission mechanism in the tropics: A narrative approach. Washington, DC: IMF, Working Paper WP/13/197.

Bernanke, B. S. (1983). Irreversibility, uncertainty, and cyclical investment. Quarterly Journal of Economics, 97 (1), 85-106.

Blinder, A. S. (1987). Credit rationing and effective supply failures. The Economic Journal, 97, 327-352.

Blundell, R. and Bond, S. (1998). Initial conditions and moment restrictions in dynamic panel-data models. Journal of Econometrics, 87 (1), 115-143.

Chirinko, R. S. (1993). Business fixed investment spending: Modelling strategies, empirical results and policy implications. Journal of Economic Literature, XXXI, 1875-1911.

Dixit, A. K. and Pindyck, R. S. (1994). Investment under Uncertainty. Princeton: Princeton University Press.

Du Plessis, S. A. (2002). Evaluating the SARB's inflation target. The South African Journal of Economics, 70 (6), 982-1007.

Du Plessis, S. A. (2014). Post-crisis reading of the 'Role of Monetary Policy'. Cape Town, South Africa: Economic Research Southern Africa (ERSA), Working Paper 419.

Easterly, W. (2002). An identity crisis? Testing IMF financial planning. Washigton, DC: Center for Global Development, Working Paper No. 9 (August). 
Fazzari, S. M., Hubbard, R. G. and Petersen, B. C. (1988). Financing Constraints and Corporate Investment. Brookings Papers on Economic Activity, 1, 141-195.

Fazzari, S. M., Hubbard, R. G. and Petersen, B. C. (2000). Financing constraints and corporate investment: Response to Kaplan and Zingales. Cambridge, MA: NBER, Working Paper 5462.

Fielding, D. (1997). Aggregate investment in South Africa: A model with implications for political freedom. Oxford Bulletin of Economics and Statistics, 59 (3), 349369.

Fielding, D. (1999). How does a central bank react to changes in government borrowing? Evidence from Africa. Journal of Development Economics, 59, 531-552.

Fischer, F., Lundgren, C. and Jahjah, S. (2013). Making monetary policy more effective: The case of the Democratic Republic of the Congo. Washington, DC: IMF, Working Paper WP/13/226.

Friedman, M. (1968). The role of monetary policy. American Economic Review, 58 (March), 1-17.

Heintz, J. and Ndikumana, L. (2011). Is there a case for formal inflation targeting in subSaharan Africa? Journal of African Economies, Supplement 2 (May), ii67-ii103.

Honohan, P. and O'Connell, S. (2008). Contrasting monetary regimes in Africa. In M. Ncube (Ed.), Financial Systems and Monetary Policy in Africa (pp. 57-88). Nairobi, Kenya: African Economic Research Consortium.

Howells, P. G. A. (1995). The demand for endogenous money. Journal of Post Keynesian Economics, 18 (1), 89-107.

Jorgenson, D. W. (1971). Econometric studies of investment behaviour: A survey. Journal of Economic Literature, 9 (4), 1111-1147.

Junankar, P. N. (1973). Investment: Theories and Evidence. London: Macmillan.

Kaplan, S. and Zingales, L. Do investment-cash flow sensitivities provide useful measures of financing constraints? Quarterly Journal of Economics, 112 (1), 169215.

Kasekende, L. and Brownbridge, M. (2011). Post-crisis monetary policy frameworks in sub-Saharan Africa. African Development Review, 23 (2), 190-201.

Keynes, J. M. (1973). The Collected Writings of John Maynard Keynes. London: Macmillan.

McKinnon, R. I. (1973). Money and Capital in Economic Development. Washington, D.C.: Brookings Institution.

Moore, B. J. (1989). The endogeneity of credit money. Review of Political Economy, 1 (1), 65-93.

Ndikumana, L. (2000). Financial determinants of domestic investment in Sub-Saharan Africa: Evidence from panel data. World Development, 28 (2), 381-400.

Ndikumana, L. (2005). Financial development, financial structure, and domestic investment: International evidence. Journal of International Money and Finance, 24 (4), 651-673.

Nickell, S. J. (1978). The Investment Decision of Firms. Cambridge: Cambridge University Press.

Nkurunziza, J. D., Ndikumana, L. and Nyamoya, P. (2012). The financial sector in Burundi. Cambridge, MA: NBER, Working Paper No. 18289. 
O'Connell, S. A. (2011). Towards a Rule-based Approach to Monetary Policy Evaluation in Sub-Saharan Africa. Journal of African Economies, 20 (AERC Supplement 2), ii36-ii66.

Padayachee, V. (2001). Central bank transformation in a globalized world: the Reserve Bank in post-apartheid South Africa. Journal of International Development, 13, 741-765.

Pollin, R. (1991). Two theories of money supply endogeneity: some empirical evidence. Journal of Post Keynesian Economics 13 (3), 366-396.

Porter, N. and Yao, J. Y. (2005). 'Inflation targeting lite' in small open economies: The case of Mauritius. Washington DC: IMF, Working Paper WP/05/172.

Sargent, T. J. and Wallace, N. (1981). Some unpleasant monetarist arithmetics. Federal Reserve Bank of Mineapolis Quarterly Review, 5 (Fall) (3), 1-17.

South African Institute for Race Relations. (2000). South Africa Survey 2000/2001. Johannesburg: SAIRR.

South African Reserve Bank. (2001). Monetary policy frameworks in Africa. Proceedings from the Conference on Monetary Policy Frameworks in Africa. Pretoria, 17-19 September.

Stiglitz, J. and Weiss, A. (1981). Credit rationing in markets with imperfect information. American Economic Review, 71 (3), 393-410.

Stone, M. R. (2003). Inflation Targeting Lite. Washington, DC: IMF Working Paper $03 / 12$

Tumusiime-Mutebile, E. (2014). How monetary targeting frameworks can tame inflation in East Africa The East African, Saturday, April 5.

UNCTAD. (2014). Economic Development in Africa Report 2014: Catalyzing Investment for Transformative Growth in Africa. Geneva: UNCTAD. 


\section{Appendix}

Table A.1: Regression variables and data sources

\begin{tabular}{l|l|l|}
\hline Variable name and symbol & Definition & Source \\
\hline $\begin{array}{l}\text { Gross domestic } \\
\text { investment }\end{array}$ & Gross capital formation (\% of GDP) & WDI \\
Trade & Imports + exports (\% of GDP) & \\
Growth & Real GDP growth (\%, annual) & WDI \\
Lending interest rate & Lending interest rate (\%) & WDI \\
Discount rate & Discount rate (\%) & WDI \\
Treasury bill rate & Treasury bill rate (\%) & IFS \\
Political freedom & Average of political rights and civil liberty & WDI \\
& indexes & Freedom \\
\hline
\end{tabular}

Acronyms: WDI = World Bank's World Development Indicators; IFS = IMF's International Financial Statistics. Sample: 37 Sub-Saharan African countries, over 1980-2012: Angola, Benin, Botswana, Burkina, Burundi, Cameroon, Central African Republic, Chad, Dem. Rep. of Congo, Rep. of Congo, Côte d'Ivoire, Ethiopia, Gabon, Gambia, Ghana, Kenya, Lesotho, Madagascar, Malawi, Mali, Mauritania, Mauritius, Mozambique, Namibia, Niger, Nigeria, Rwanda, Senegal, Sierra, South Africa, Sudan, Swaziland, Tanzania, Togo, Uganda, Zambia, Zimbabwe.

Table A.2: Summary statistics

\begin{tabular}{|l|r|r|r|r|r|}
\hline Variable & \# Obs. & Mean & Std. Dev. & Min & Max \\
\hline Gross domestic investment (\% of GD) & 1188 & 19.4 & 9.3 & 0.3 & 74.8 \\
\hline Bank credit to private sector (\% of GDP) & 1138 & 16.5 & 14.2 & 0.7 & 100.7 \\
\hline Total trade (\% of GDP) & 1193 & 70.0 & 37.0 & 6.3 & 209.9 \\
\hline Real GDP growth (annual \%) & 1199 & 3.6 & 5.6 & -50.3 & 35.2 \\
\hline Real lending rate (\%) & 894 & 20.8 & 18.6 & 6.0 & 278.9 \\
\hline Treasury bill rate (\%) & 894 & 16.9 & 16.2 & 0.1 & 217.9 \\
\hline Discount rate (\%) & 610 & 16.5 & 22.4 & 2.0 & 238.0 \\
\hline Political freedom index (min 0 to max 6) & 1213 & 2.2 & 1.6 & 0.0 & 6.0 \\
\hline
\end{tabular}

Source: See Table A1 for data sources. 